\title{
THE WILLOWES PATTERN Rosemary Sykes
}

The theme of the Willowes family's "canons of behaviour," (p.7) ${ }^{1}$, their "family traditions"(p.65) and "old fashioned ways"(p.7) is apparent from the start of Lolly Willowes and reiterated throughout the first two parts of the novel, the sections that narrate the family's history from the eighteenth century to 1922 .

I believe that, in Lolly Willowes, Sylvia Townsend Warner is highlighting the way in which thought, tastes and aspirations are reined in by the need to bend to tradition, and then-because they are "traditional"-they are adhered to without question. Whilst this is a novel that has not become canonical it is-nonetheless-a text that is fully aware of how things become canonical.

The Willowes pattern is shown both to mirror trends within the middle class over three centuries, and to be one that fuses and confuses the material with the moral. This fusion within the Willowes pattern is underscored by a punning use of motifs which (through repetition, metaphor and metonymy) become ideological symbols: "Willowes" is the name of a family which sets great store by its family tree; one which thinks of itself as dynastic and immemorial, as "the house of Willowes"(p.9). It actually turns out to be the contents of the Willowes houses (especially the furniture and the books) that regulate the Willowes traditions, even though the Willowes homes are, themselves, regulated in "traditional" ways. Indeed, Warner even uses the family furniture to show how tradition is (literally) furnished. 
Her complex network of symbolic puns reveals the equally complex links between the patriarchal values of property, proprietorship and propriety-the materialism that (sometimes imperceptibly) informs middle-class mores becomes increasingly obvious until the twentieth centuryand she also unveils the social niceties (and barely-concealed desires) that surround the vexatious notions of inheritance. The marriage of Laura's father, Everard, to a second cousin strengthens the Willowes pattern in his branch of the family still further, for Miss Frances D'Urfey brought some more Willowes property to the Somerset house, including a "tea service bequeathed to her by the Admiral, an amateur of china, who ... dowered all his nieces . . . with Worcester, Minton and Oriental."(p.11)

The family's roots are traced back to Titus Willowes of Dorset, who "made a voyage to the Indies and . . brought back with him a green parrokeet [sic], the first of its kind seen in Dorset."(p.8). At this remove from the twentiethcentury Willoweses, dates of birth are not mentioned, and even the exact degree of relationship of the early relatives to Laura's branch of the family is vague; for what makes these early ancestors' lives sufficiently memorable to be narratable is not precise genealogical detail but anecdotal information and the heirlooms they bequeath. And the heirlooms that render lives narratable stress the notion of a Willowes pattern. Though Warner never mentions willow pattern china, hints of this motif will be seen in almost all the Willowes heirlooms: the admiral's dowering his nieces with china, for instance, has already been mentioned, and Ratafee is stuffed after his death and sits-as in life-perched on a ring "on the cornice of the china-cabinet"(p.8, italics added). It is Ratafee who ensures that Titus is remembered, giving an early example of the Willowes passion for possessions. Titus is the father of great-great-aunt Salome, whose recipes and prayer-book will guide the Willowes family for generations. Salome is considered as the member of the family who, perhaps, had made the nearest approach to fame. It was a decent family boast that great-great-aunt Salome's puff-paste had been commended by King George III.(p.7) 
The Willowes family prides itself on its decorum, but Warner gently mocks such notions; the idea of a "decent" (as in "fitting") boast acquires ambiguous overtones: for the juxtaposition of the boast with puff-paste suggests, connotatively, the emptiness of an advertising "puff", making such decorum appear somewhat absurd. And what is the value of a commendation from a ruler who went mad? Warner's waspish wit is marked here: Salome is a delightfully inappropriate name for the wife of a Canon, for a "loyal subject, a devout churchwoman and a good housewife"-most unlike her biblical namesake.

The next relative to be described-because her harp stands beside the china cabinet from which Ratafee hangs-is Laura's great-aunt Emma. But she also leaves an eerier heirloom (which in this particular case should, perhaps, be deliberately mispronounced as "hairloom"):

Emma had died of a decline, and when she lay dead ... a lock of her hair was cut off to be embroidered into a picture of a willow tree exhaling its branches above a padded white satin tomb. "That," said Laura's mother, "Is an heirloom of your great-aunt Emma who died." And Laura was sorry for the poor young lady who alone, it seemed to her, of all her relations had had the misfortune to die.(p.9)

The cushion bears the motif of the willow tree that appears on willow pattern china; Aunt Emma bequeaths the motif of the declining woman to the Willowes pattern but subsequent generations will each deploy it differently. Laura's mother (doubly a Willowes, by birth and by marriage) "during the last few years of her life ... grew continually more skilled in evading responsibilities, and her death seemed but the final perfected expression of this skill."(p.18) Following Emma's physical decline, and Mrs Willowes's perfected declining of responsibilities, Laura moves beyond such Victorian tropes of femininity and (in terms of the time she lived in) elevates the notion of the declining woman into a more adventurous and contentious frame: displaying a "temperamental indifference"(p.26), she declines to marry.

Needless to say, however, Laura is not the only member 
of the family not to produce new Willoweses, nor are Aunt Emma and Mrs Willowes the only members of the Willowes family tree to have had the misfortune to die. Aunt Emma's passing is immediately followed (textually, at least) by a passage about Laura's grandfather Henry "born in 1818" (here, for the first time, a precise date is given) and the fact that Henry only became "head of the house of Willowes" because his father and an unmarried elder brother had died of small pox when Henry was twenty-four ${ }^{2}$. A multiple hiatus underlies the text here; one break causes many fractures in the Willowes pattern. Both these ancestors remain un-named and they do not appear to have left any exciting heirlooms about which to tell tales. Furthermore, their deaths cause the family seat of the "house of Willowes" to move from Dorset to Somerset, where Henry-who "had shown a roving and untraditional temperament"(p.9)-had entered into partnership in a brewery. When he becomes the family's head, Henry refuses to give up either his career or his adopted county even though "it was natural to expect that ... Henry would . . . at least ... return to his native place"(p.10).

The "family annals" remain silent on how the Willowes family had hitherto gained its wealth and status. But a hint has been given by the earlier mention of Titus and his "parrokeet". If Henry's "roving" is linked to an "untraditional temperament" the implication is that Titus did not "rove": that his voyage to the Indies was a business mission. Is the family income, perhaps, derived from sugar plantations? Even in Somerset Ratafee continues to overlook the Willoweses from the china cabinet: his glass-eyed gaze surveys "four generations of the Willowes family"(p.8). Warner emphasizes this colonial gaze (as one might call it) and the importance of the "parrokeet", as symbol of colonialism, as well as family heirloom.

Though the bird made "county history" it is the Willowes family's history that is called into question. Early in the nineteenth century Ratafee's eye fell out. Why is not explained; ${ }^{3}$ did it, perhaps, coincide with the abolition of slavery? Whatever the reason, the lacklustre inferiority of 
the new glass eye perhaps reflects a waning in the family's fortunes, a suspicion reinforced by the fact that neither the great-great grandfather, nor his heir apparent, is ever dignified with a Christian name.

But the deflection of "the leering look" also reflects changes in British society and economic power, with the move from land-owning to industry. Two generations later socio-economic shifts again become apparent as Laura's brother Henry eschews the family brewing business, choosing to become a lawyer. In doing so-because a teacher, having heard him speak in the School Debating Society, "told him that he had a legal mind"(p.22)-Henry provides an early example of manners of speaking becoming manners of being: something that will be still more explicit in Laura's case. His choice of career reflects a historical trend towards increasing employment in the professions during the lateVictorian era. In deviating from the family business, he also upsets his parents (his father is "hurt", his mother "had the old-fashioned prejudice against the learned professions") yet, paradoxically, through his deviation, he repeats the pattern set by his grandfather: the brewery, "untraditional as it was, soon became indistinguishably part of the Willowes way of life."(p.11)

Henry's move into the legal profession takes him to London, and James (himself a younger brother, like the grandfather who moved the family into brewing) becomes a partner in the brewery, thus remaining (even after his marriage) at Lady Place, with his father and sister. When Henry and Caroline produce their daughters Fancy and Marion, Henry apologises to his father for "the accident of their sex." In "his fears for the Willowes' male line"(p.34) Henry has failed to consider that it might be his younger brother who sires the future heir, but James and his wife produce Titus. So, when Everard dies, there is a complex knot: though Henry is the elder son, it is the younger son who lives in the family seat, and the younger son is also father of the future heir. It is in the midst of these complications in the house of Willowes that Lolly Willowes begins. 
A swift tour of the Willoweses' houses will reveal the class and gender assumptions that inform the Willowes tradition, and also the many tensions and contradictions that lie beneath the supposed continuity of that tradition. The patriarchal patterns of the Willowes family are implicit in the first sentence of Lolly Willowes:

When her father died, Laura Willowes went to live in London with her elder brother and his family.(p.1)

Laura is regarded as dependent upon her male relatives and the provision of a home-the bricks and mortar that form it, the money that maintains it-is presented as a male responsibility. But the domestic space within the walls, the space in which the family wishes to contain Laura, is shown to be the domestic sphere; it is Caroline, Laura's sister-inlaw, who issues the edict (it is not phrased as an invitation) that Laura will leave Lady Place: “ 'Of course,' . . 'you will come to us' "(p.1). Caroline's thoughts rapidly turn to furnishing the "small spare-room" for Laura, even as she assures her that she will be welcome in London.

Laura's father's death is a pivotal moment: it draws together the three main family residences; propelling Laura from her childhood home at Lady Place (Somerset) to her brother's house in Apsley Terrace (London) but also, briefly, returning the family to its Dorset roots for Everard's funeral. For though, on becoming head of the house of Willowes, Grandfather Henry-"followed by a patriarchal train of manservants and maidservants, mares, geldings ... vans full of household stuff"(p.38)-states that he is "going to Lady Place for life", we are also told that "death was another matter". The Willowes burial ground remains in Dorset, emphasising the family's roots even as the "house" moves. And after Everard's funeral, in that same burial ground, Laura looks at the old house:

A prescience of exile came over her and, forgetting Lady Place, she looked with the yearning of an outcast at the dwelling so long ago discarded. The house was like an old blind nurse sitting in the sun and ruminating past events.(p.41) 
Warner plays tricks with the notion of "the house of Willowes". Buildings come alive, people are described as parts of buildings. In Laura's eyes the Willowes houses may be seen as almost human; as she considers her future life in London she muses upon the Apsley Terrace house, and how her growing familiarity with it will mean that she will eventually "recognise a special something in the physiognomy of that housefront"(p.3).

The narrator reveals a different view of these two homes. The family annals make no mention of a farming past, but, at the funeral, the Willoweses' earliest origins are unearthed: the drive along which Laura glances at the old home is "long, straight and formal" but once "it had beèn a cart track ... when the old house was a farm"(p.41). The Apsley Terrace house is described as a living organism; but the unconscious processes of breathing and digestion (automatic within a person) are revealed as the work of the family's servants engaged in a diurnal cycle of destruction and rebirth:

unseen and underground the preparation and demolition of everyday work went on, like the inward persistent workings of entrails. Sometimes a crash ... would rend the veil of impersonality ... sometimes a sound of running water at unusual hours and a faint steaminess in the upper parts of the house betokened that one of the servants was having a bath.(p.47)

Here the device of animating the house-a precursor of Warner's switch from realism to fantasy-whilst simultaneously stressing its (paradoxical) veil of impersonality, shows how much Henry and Caroline take their servants for granted and how firmly they confine them above and below the family's living quarters. This notion of stations within the house of Willowes is reprised when, during the war, a lady inquires of Henry whether the family goes "down into the cellar or up on the roof" during air-raids, and he tells her: "we do neither... we stay where we are"(p.71). His words are described as a "statement of the Willowes mind", but 
they seem also to be a statement of the rigidly enforced hierarchy in Henry's house. Everard's household at Lady Place, where the servants' domestic routine is very much part of the family tradition, forms a marked contrast. Warner underlines the almost symbiotic relationship of family and servants in Lady Place through the name she chooses for one of them: "Brewer" is the gardener of a brewing family and it is Brewer who recognises that Laura is diminished by her removal from Lady Place. Henry and Caroline will admit to no such interdependence; they do not hold with the old values of Grandfather Henry's patriarchal train, but-"half-hidden under their accumulations . . . of prosperity, authority, daily experience"(p.89)-they represent the extreme of the materialistic trend of the Willowes pattern.

Caroline and Henry also embody the institution of marriage and the heterosexual traditions geared towards reproducing the status quo (albeit through the production of a new generation to carry on the family tree). That marriage is an edifice, rather than a sacrament, becomes plain when the narrator describes Henry and Caroline in terms that, though influenced by the Song of Songs, make the couple sound more like a cathedral, castle or a walled city, than humans:

They could look after Lolly. Henry was like a wall, and Caroline's breasts were like towers.(p.81)

Whether "they can look after Lolly" turns out to be a moot point; though they have become agitated by "naughty" Lolly's extravagant expenditure, Henry turns out to have invested Laura's money unwisely. This is only revealed when Henry tries to persuade Laura not to leave Apsley Terrace, when the force of propriety (or should I say the force of proprietorship?) - "I must ask you to put this ridiculous idea out of your head"(p.100)-fails; obliging Henry to reveal that her income is "no longer what it was"(p.102). Laura, undaunted, rents rooms in Great Mop, finally beginning to come into her own by gaining her own domestic space to manage; a space that is not furnished by the institution of marriage. 
A woman who enjoys domesticity whilst eschewing marriage is difficult to place within the gendered spheres of the Willowes households: a spinster cannot be mistress if her sister-in-law is present. Laura enjoys managing Lady Place after her mother's death, but she has to cede her role as housekeeper when James marries, because "it seemed proper". Propriety further dictates that the two women have to perform a mannered dance of politesse; they dispute the point "with much civility, each insisting upon the other's claim like two queens curtseying in a doorway." It is a preposterous image, but in mentioning queens the narrator reminds the reader that this is a struggle of dynastic import. Is this why Laura is sent to live in London, rather than being allowed to remain in her childhood home? As she departs, Sybil tells her that she "mustn't quite forsake Lady Place"(p.5) but this is precisely what she is obliged to do. Three years later, however, James follows Everard to the grave, the brewery is left in the hands of a manager and "Sibyl and the four-years-old heir of the Willowes name and traditions move ... to a small house in Hampstead"(p.63).

James's death and Sibyl's removal to Hampstead mean that, until Titus comes of age, the tradition of the "house of Willowes" will only be housed in the mind, its continuity embodied by, and dependent upon, a twist of the metaphor. Laura notes, with approval, Henry's pragmatic accommodation of the new situation: "Henry could house all the family traditions in his practical mind, and for the rest talk about bricks and mortar."(p.65)

The reader is already aware that, though the Willowes family likes to adhere to its "canons of behaviour", all that actually remains constant within the Willowes tradition is the idea that there is a Willowes tradition-an "inherent responsibility of being a Willowes"(p.23), a "Willowes decorum"(p.27). Yet Henry's notion of the Willowes pattern remains one that both invests, and is invested, in its material aspects. Henry, "showing a great deal of Willowes spirit"(p.64) refuses to allow Sybil to sell the surplus furniture from Lady Place: "the family establishment must, he admitted, be broken up, but he would allow no part of it 
to be alienated." The narrator points out that the furniture that now rouses Henry's "Willowes spirit" is the same furniture that had "sanctified" the "Sacrilegious move" to Somerset, masking the rupture caused by the removal of the Willowes "seat" (and its china cabinet) to Lady Place. The sardonic use of religious terms reveals how the family's tradition has become a religion, with the furniture as its ritual display of faith. The Willoweses' furniture and books are shown both to create and enforce the semblance of a continuum; Warner exposes tradition as a strategic device. Moreover-whilst it is not my intention to suggest that direct parallels may be drawn between the two-I would argue that a comparison of the Willowes pattern of (material, moral) tradition with T.S. Eliot's discussion of literary tradition ${ }^{4}$ will show how Warner's use of the family furniture parodically reveals the hidden assumptions, elisions and contradictions latent within any encompassing notion of tradition.

When Laura allows Henry and Caroline to sweep her off to London, Warner does not present her passivity as merely being the meek compliance of a spinster to the social conventions of her time. Her emphasis is also, expressly, on showing Laura as a product of her family's traditions:

Laura, feeling rather as if she were a piece of family property forgotten in the will, was ready to be disposed of as they should think best.

The point of view was old-fashioned, but the Willoweses were a conservative family and kept to old-fashioned ways. Preference, not prejudice, made them faithful to their past. They slept upon beds and sat upon chairs whose comfort insensibly persuaded them into respect for the good sense of their forbears. Finding that well-chosen wood and wellchosen wine improved with keeping, they believed that the same law applied to well-chosen ways. Moderation, civil speaking, leisure of the mind and a handsome simplicity were canons of behaviour imposed upon them by the example of their ancestors.(pp.6-7)

At first glance these "canons of behaviour" may appear to be based on "tradition" of the sort that T.S. Eliot cautioned against: "if the only form of tradition, of handing down, consisted in following the ways of the immediate 
generation before us in a blind and timid adherence to its success, 'tradition' should be discouraged." 5

The Willowes ways are automatic, and the present generation adheres to them believing that they have chosen to do so-that this is their "preference"-when, in fact, the choice is "imposed upon them by ... example." This inertia means that even small departures from the pattern can be seen as outrageous, as when James returns to the family home in Somerset after his mother's death:

Soon after his return he did a thing so unprecedented in the annals of the family that it could only be explained by the extreme exaltation of mind that possessed him: for, without consulting any one, he altered the furniture, transferring a mirror and an almond-green brocade settee from his mother's room to his own.(p.21)

After such a build-up ("unprecedented", "extreme") James's action strikes the reader as jarringly bathetic. Warner certainly pokes fun at the "blind and timid adherence to success" that Eliot mocks, but she also shows how tradition itself-in placing an emphasis on its visible, outward trappings-reifies and reinforces ideology. Warner's description of the Willoweses' “canons", for instance, reveals a materialistic and ideological foundation (albeit one that the family members are "insensibly" aware of); one that stresses a link between belongings and behaviour, and a curious logic which privileges objects over ideas: because the furniture is comfortable, so the ways of the people who had owned the furniture are considered to be preferable. But preferable to what? Though the Willowes tradition is "founded on preference, not prejudice" no other options appear to be considered. Eliot suggests that whilst "existing monuments form an ideal order within themselves", new works will alter the traditional structure, "if ever so slightly." The present is, thus, understood to reshape the past. Eliot, however, appears blind to his own role in this refashioning. It is not the new work itself that alters the structure; the transformation is effected by the citric who seeks to suggest that the new work is traditional, so that the illusion of an "ideal order" may be maintained. 
In the Willowes pattern it seems, at first, to be the past that re-forms the present for, despite the consternation he causes, James Willowes is not the first of the Willoweses to move the family furniture. Those pieces of furniture are only at Lady Place because of the hiatus in the family tree three generations earlier. How ironic that the family's preferences are established by sitting upon the chairs of the ancestors whose deaths were the only narratable features of their lives, upon the chairs that are only in their branch of the family tree because of those deaths. That move, as I have already mentioned, masks a change in the family's socio-economic status, as well as its geographical locus, but a certain continuity with the family's past is ensured by recreating the arrangement of the furniture in the Dorset house:

In the main the Willowes tradition stood the move very well. The tables and chairs and cabinets stood on the same relation to each other as before.(p.11)

This, too, is to maintain the illusion of an ideal order: drastic changes may take place in the family's fortunes, but propriety is ensured providing that the furniture is arranged as it always has been or if-at the very least-it is put into storage until such time as the Willowes heir will sit upon a comfortable seat, thus enabling the Willowes decorum to be "insensibly" installed into another generation.

One advantage of using "tradition" as a yardstick of taste (as Eliot does) or as a yardstick of propriety (as the Willowes family does) is that tradition is always fashioned with hindsight: it is a construct which may be altered to suit current trends, or one's current needs and concerns, under the guise of perpetuity. That tradition is very much preoccupied with ideological values-predetermined preferences-is revealed in Eliot's statement that "we do not quite say that the new is more valuable because it fits in; but its fitting in is a test of its value". Here, Eliot uses a double-standard: he has already argued that tradition is altered by the incorporation of new works-without admitting that "tradition" is a 
construct, rather than a given-yet the extent to which a new work "fits in" is a test of its value. Eliot personifies tradition as "the mind of Europe", as a "mind which changes" but one which, he claims, is all-embracing: "this change is a development which abandons nothing en route, which does not superannuate either Shakespeare, or Homer, or the rock drawings of the Magdalenian draughtsmen." Eliot overlooks the fact that his very notion of tradition creates a canon that operates by exclusion and elision, as much as by inclusion.

Warner demonstrates how an insistence that tradition is being adhered to swiftly conceals change, as the new becomes "traditional". Like Eliot, the Willowes family has its notions of "fitting in . . a a a test of value". The arrangement of the furniture represents "normal" behaviour, implying a link between the moral and the material, providing a dramatic, and dramatized, example of a trend Nancy Armstrong has identified as being enforced through the agency of fiction within which it appears:

I regard fiction . . . as both the document and the agency of cultural history. I believe it helped to formulate the ordered space we now recognize as the household, made that space totally functional and used it as the context for representing normal behaviour. In doing so, fiction contested and finally suppresses alternative bases for human relationship. ${ }^{6}$

Armstrong sees the "ordered space" as the result of a stress on gender differences that creates so strong a focus that it occludes other differences or inequalities within society (class, say, or religion) enabling the material capitalism of the middle class to be accepted unquestioningly. Warner recognised these same trends. And in focussing on furniture, as much as domestic space, Warner has emphasised the materialism that underpins the Willowes tradition. When, after James's death, the domestic space of the family seat is no longer under the family's immediate control, the furniture itself acquires an even greater importance; as the conduit of a future return to the ideal. The Willoweses are, thus, able to uphold standards of propriety through using 
furniture to provide status quo, just as Eliot uses "tradition" and "the mind of Europe" to justify his own critical intervention and bias; and just as Armstrong shows fiction as concealing and reinforcing middle-class hegemony.

In playing with implied, as well as fully realized, puns Warner challenges the reader to recognize the extent to which anyone's thinking is-to borrow a phrase from Gillian Beer's discussion of representation-"at the mercy of our communal metaphors".7 Here, however, I shall focus upon Warner's use of a metonymic displacement and a synecdochic reduction to reveal the extent of the fusion of, and confusion between, the material and the ideal in the Willoweses' "canons of behaviour." In her article on representation, Beer discusses the way in which ideologies can "harden into objects and so sustain themselves in the real world. . . . Their encoding of assumptions and desires reinforces as natural and permanent what may be temporary and learnt"(p.64). The "objects" Beer lists include books, film and fashion. No furniture is mentioned, but the Willowes' fetishization of the family furniture provides a clear example of the ideology of materialism, and of the ideals of decorous middle-class behaviour being transmitted through a material object. But it is with a book that the rootedness of the Willowes stress on possessions and Willowes ways becomes most obvious, and affects Laura most deeply.

Critical essays and novels are comparatively recent ways of disseminating ideology through text; the Bible has been doing so for countless generations. In many families it is traditional to record the family tree in the Bible; no mention is made, however, of a Willowes family Bible. ${ }^{8}$ The canonical text that regulates the Willowes canons of behaviour is the prayer-book that belonged to the wife of a Canon of Salisbury. Great-great-aunt Salome's prayer-book is an Anglican one, as is befitting for the wife of a Canon. It is passed from generation to generation and "always used by the wife of the head of the family"(p.7), though not always unproblematically: "for several Sundays" Grandfather Henry's (Welsh, hitherto Evangelical) wife is distressed by the "goings on" that she finds within it(p.11). Precisely 
which "goings on" she objected to we are not told, but Warner very deliberately presents the prayer-book "with the services for King Charles the Martyr and the Restoration of the Royal Family and the Welfare of the House of Hanover"(p.7) as a political text. A throwaway remark appended to this list of services underscores the point: "a nice example of impartial piety." Warner directs the reader's attention towards the Interregnum, the Puritan interlude so at odds with the Willowes' Love of possessions. Changes in the ruling house are acceptable, but not the elimination of the monarch: we are reminded that the Head of the Church is also the Head of State. That this is seen as "proper" is revealed by the fact that Oliver Cromwell is a toad-one with whom Laura plays as a small girl(p.14) (anticipating her flirtation with Satan, perhaps)-and the dynasticism of the prayer-book is, of course, matched by the Willoweses themselves. Religion is bound up with state and family; God seems very remote. Caroline (current bearer of great-greataunt Salome's prayer-book) is frequently described as a "religious" person, but in ways that suggest frigidity. She is "a married nun" and "would have made an admirable Mother Superior". When she is likened to a mystic-"like all true mystics she was unsympathetic and difficult to approach"(p.51) - the effect is only to stress her materialism; it is not because "her housekeeping and her scrupulous account books ... expressed an almost mystical sense of the validity of small things."(p.51)

The Willowes pattern forbids Laura the luxury of theological thought (yet in the library at Lady Place she is let loose upon an extraordinary variety of texts). Though she is described as "not in any way religious ... not even religious enough to speculate towards irreligion"(p.52); when bored by attendance at the family church she expresses a desire to "see the world, to adventure in churches"(p.53). Laura wants to visit a range of Christian churches-"Roman Catholics, ... Huguenots, . . . Unitarian and Swendenborgians"-a range that encompasses almost every possible interpretation of the Trinity and of how behaviour in life will affect one's destiny in the afterlife, though-note-there is no mention of any of 
the "traditional" non-conformist/dissenting churches: Laura is not yet so bold. Caroline "rather unexpectedly" approves of Laura's plan. But Laura is stopped in her tracks by Henry's belief in the sanctity of aunt Salome's prayer-book. Laura's horizons are reduced by Henry's insistence that "the family place of worship was the pew upon whose ledge rested great-great-aunt Salome's prayer-book"(p.53). The narrator has already alerted us that the prayer-book is, simultaneously, the reification of the Willowes ideology, and the metonymic reduction of belief to a book of observance:

Religion was a strand in the Willowes' life, ... the prayer-book was the outward sign of it. But it was also the sign of the puff pastry which had been praised by King George III. Religion was something to be preserved: it was part of the Willowes life and so was the prayer-book, preserved from generation to generation.(p.53)

The prayer-book has become a symbol so devoid of religious belief that it can also be the sign of the empty boast about aunt Salome's puff paste. Yet it still remains so powerful a symbol of the Willowes ways that Henry can use it to keep Laura in the family pew (though the book is held in Caroline's "gloved hand", it is Henry who remains the proprietor of the Willowes ways). The book that objectifies the Willowes ideology, and that leads to its naturalization, refers back to the time when church and state were thrown into chaos by war. Yet is also proves that "normality" was eventually restored. This, then, is the great act of faith for the Willowes family, that-despite change, and with an emphasis on outward appearances-their ideal will continue. Great-great-aunt Salome's prayer-book enshrines and sacralises the notion that tradition can occur. 
Notes

1. All page references are to the Virago edition (1993), which is offset from the Chatto \& Windus 1926 first edition.

2. Smallpox and perpetuating the family line are linked elsewhere in Warner's fiction: in Summer Will Show (1936) it causes the death of Sophia Willoughby's children (children whom she thinks of as perpetuating the line of her side of the family, describing them-with herself at the apex-as "the Aspen triangle", just as she had been at the apex-"the point advancing on the future, as it were"-of an earlier version of the Aspen triangle with her parents. (And note also how the surnames chosen-Willoughby and Aspen-pun, like Willowes, on the notion of the family tree).

3. It is not likely to have been during the move to Lady Place, since this happened in 1842, which is not "early" in the century.

4. Eliot's was one of the most compelling critical projects available at the time that Warner first entered literary circles.

5. "Tradition and the Individual Talent" (1919).

6. Armstrong, Nancy; Desire and domestic Fiction: a political bistory of the novel, Oxford University Press, 1987, pp.23-24.

7. Beer, Gillian "Representing Women: Re-presenting the Past" in Catherine Belsey and Jane Moore (eds), The Feminist Reader; Macmillan, London 1978, p.70.

8. Note, however, that Laura makes several Biblical allusions. 


\section{Copyrighted image removed}

Lolly Willowes by Reynolds Stone from the combined Lolly Willowes/Mr Fortune's Maggot edition, Chatto \& Windus/Viking Press, 1966. 